International Research Journal of Management, IT \& Social Sciences
Available online at https://sloap.org/journals/index.php/irjmis/
Vol. 6 No. 5, September 2019, pages: 279 284
ISSN: 2395-7492
https://doi.org/10.21744/irjmis.v6n5.744

\title{
Church Efforts on Strengthening Women Capacity to Fight Household Violence in Kupang
}

\author{
Mesakh Abia Pello Dethan ${ }^{a}$ \\ Fredrik Y. A. Doeka ${ }^{b}$ \\ Leni Hanna Flolinda Mansopu ${ }^{c}$ \\ Rinto Rame Laki ${ }^{\mathrm{d}}$
}

Article history:

Received: 09 March 2019

Accepted: 31 July 2019

Published: 19 September 2019

\section{Keywords:}

church efforts;

strengthening capacity;

household violence;

violence;

women;

\begin{abstract}
This research aims to investigate how far handling of the Christian Evangelical Church in Timor (GMIT) Efata Liliba against violence in the household $(K D R T)$ occurring in women, which can be used as a study and learning materials in preventing and overcoming violence against women. The method used in this research is a qualitative method of research. The qualitative approach of research is chosen because it emphasizes the phenomenon/fact, the meaning of reasoning, certain situations (in certain contexts), or more researching matters relating to the daily life of women who become the victim of violence in a household $(K D R T)$. From the results of the study found that the factors causing the violence in the household (KDRT) because of economic pressures, husbands are average drunkard and love to gamble. The profession of the wife as a housewife and only relies economically on husbands who are drunkard and love to gamble cause violence in a household as if it gets a fertile place. The efforts of GMIT Efata Liliba by strengthening the capacity of women to fight the violence in the household through the economic empowerment of women in the local church is apparently fruitful results. The woman who is economically strong and her mentality is able to dampen the acts of violence in the household.
\end{abstract}

2395-7492@ Copyright 2019. The Author. This is an open-access article under the CC BY-SA license (https://creativecommons.org/licenses/by-sa/4.0/) All rights reserved.

\section{Author correspondence:}

Mesakh Abia Pello Dethan,

Artha Wacana Christian University, Kupang, Indonesia

Email address: mesdethan@yahoo.de

a Artha Wacana Christian University, Kupang, Indonesia

${ }^{\mathrm{b}}$ Artha Wacana Christian University, Kupang, Indonesia

${ }^{c}$ Artha Wacana Christian University, Kupang, Indonesia

${ }^{\mathrm{d}}$ Artha Wacana Christian University, Kupang, Indonesia 


\section{Introduction}

The rise of sexual harassment and the violence in the household (KDRT), a sign of Indonesia, is in a violent emergency against women and children. The perpetrators and predators sexually against women and children wandering around everywhere threaten the tranquillity and comfort of the Indonesian family.

In the Christian Theologia, the household is seen as a miniature of God's family to get protection. The protection is also secured in law No. 23 of 2004 on the elimination of domestic violence as a result of the inaction of a person, especially women, resulting in the onset of misery or suffering Physical, sexual, psychological, and domestic study including threats to perform acts, coercion or deprivation of independence against the law in a household environment.

Further, the elimination act of the KDRT also explains, the frequent forms of violence in households are 1). Physical abuse as an act that causes pain, illness, or severe injuries; 2). Psychic violence is the deed resulting in the loss of fear, loss of self-confidence, loss of ability to act, helplessness, and the psychic distress of the weight; 3 ). Sexual violence is the coercion of good sex to family members in the home or around, including for commercial or specific purposes; and 4). A study is an act of calling the real person according to the law to be responsible or limiting a person so that it depends and feels controlled.

However, the fact that many households suffered violence, especially women and children. The research Data of the women's house in the final note in 2015, explained that for 15 years has accompanied 1,144 cases of domestic VIOLENCE in Kupang and Kupang districts and 2015, there are 102 cases of KDRTor 25\% of the number of cases Violence and children who need to be accompanied (Rumah Perempuan Kupang, 2015; Nafi et al.,2016). The number is an overview of the cases that are revealed and addressed.

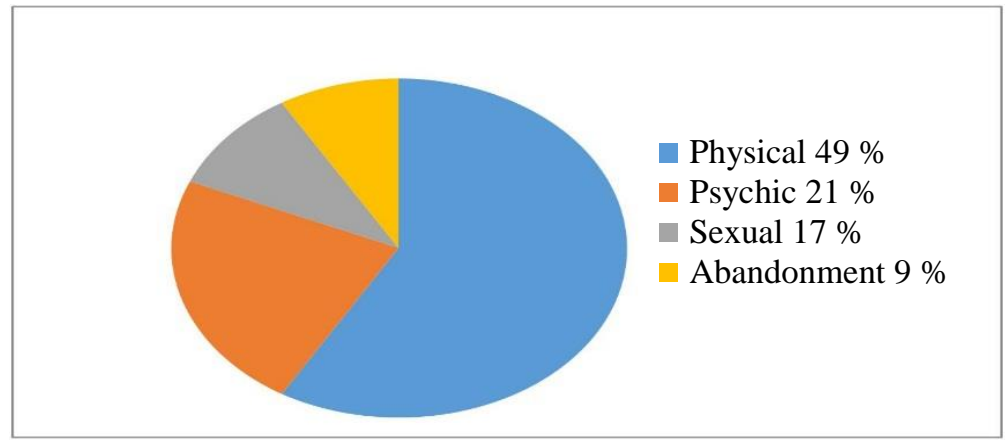

Figure 1. Data KDRT year 2015

Finally, the women's house also noted that based on the cases of domestic violence that they accompany, $49 \%$ were caused by economic factors, $19 \%$ due to verbal abuse, $19 \%$ due to lack of communication in both spouses, and the remaining $1.3 \%$ because of the affected by liquor. Looking at the fact above, the formulation of the problem here is how the church's efforts in strengthening the capacity of women to resist domestic violence (KDRT).

\section{Materials and Methods}

\subsection{The Violence in the Household (KDRT)}

The fact that the KDRT is an iceberg symptom. The data that appears to represent a much wider reality. The women's house in her companion found that "the deference of the case of domestic violence was caused by the awareness of the protection of the victims still very low" (Dewa, 2002). The violence that occurs in the family is regarded as a personal problem that should not be confused by the outside, even considered as part of the family's life seasoning. Victims are often forced to receive anything perpetrators do.

In the case of violence, the perpetrator would attempt to silence the victim to cover his violent actions (Wiryasaputra, 2006). For the victim not to speak of the violent reality that occurs, the perpetrator will tend to offer a process of peace and forgiveness. Thus violent acts become a secret that no longer wants to be told. Reconciling the perpetrator and victim is not necessarily the best way out. If with the effort the victim continues to speak, the next step that the perpetrator can use is doubting the credibility of the victim and his story. The women's victim was then accused 
of being the cause of KDRT. Thus the environment will doubt the truthfulness of the victim's story to assume that the victim fetched and no one to believe the victim let alone to the victim.

Strengthening the capacity of women to resist violence in households is possible if the Efata Liliba Church can prepare reliable escorts for the task. Mentoring is an individual or institution that conducts coaching between the parties (companion and accompanying) occurs equality, partnership, cooperation, a togetherness without any group boundary (class or social status) (Departemen Pendidikan Indonesia, 2008).

According to Natar (2018), mentoring is a four-eye meeting between the companion and the victim that contains a straight, unique and humanist effort done about the problems he faced in the future. The atmosphere of expertise is based on the prevailing norms (Dewa, 2002).

So also, according to Wiryasaputra, mentoring is the process of the relief encounter between the companion and the accompanying person. In the process of mentoring will promote interactions that can bring ideas and exits when facing the problem (Wiryasaputra, 2006).

From the above defendant can be concluded that the activities of mentoring is a cooperative process involving both parties (a companion that can be represented by the Church or a team of experts and accompanied by the victim of women of $K D R T$ ) in order to strengthen the capacity of women in combating $K D R T$ as a manifestation of church alignments towards women of KDRT.

Partiality in the victim must certainly be continued with the assistance of victims. Viktor Frankl, in his research into the victims of violence in Nazi camps about suffering, found that one of the basic human needs is the necessity for meaning (Agra et al., 2018; Jain et al., 2017). Men are happy by discovering meaning in every situation of his life, including in suffering. Furthermore, Frank explains that the invention of that meaning will lead mankind toward the orientation forward by asking by the experience of suffering "what exactly is the life expected of him?" (Hardiman \& Simmonds, 2013). This transition makes a person a survivor or person who has been able to pass through violent experiences and rise to look at life in front of him. Based on the theory of Frankl, the problem of KDRT should be addressed through thorough action. Both in the prevention phase, the level of mentoring, to the post-violent stage by making victims of domestic violence can be a subject that also struggled to remove $K D R T$.

The level of prevention can be the awareness of the community members and members of the church in the KDRT. 1). The stage of mentoring is a process of mentoring when victims suffer from KDRT. The victim cannot be left to face his problems, and 2). The post-violence phase was the stage of accompanying the victims after the time of the $K D R T$ to help victims find the meaning of his life through the experience of the KDRT experienced (Ruan, 2018; Suparna et al., 2018). Through the experience, the victim is helping the surrounding community to prevent and stop the $K D R T$ and help strengthen other victims.

\subsection{Church: A Restoring Fellowship}

The Church cannot attend to itself. The presence of the church is to realize the mission of God is the reality of the Kingdom of God, not only in heaven but also on earth. To proclaim the Kingdom of God, it should be all in the Church both the Doctrine and the directed program in fulfilling the Mission of God. Thus the nature of the Church (Being) is evident in church service (Doing) (Purwanto, 2018).

Similarly, the Evangelical Christian Church in Timor is one of the churches that God placed to declare his mission in the city of Kupang. Amid a context full of cases of KDRT, the Church should provide space in both the teaching and the program that could become the media of the church faced with the case of $K D R T$.

Awareness to seriously observe the problem of $K D R T$ has been seen in the GMIT's ecclesiological manuscripts of Christian families. GMIT understands that the family is a living base of the church. A Christian family as a family in which the values of Christianity were built and developed are the point of service that does not escape many problems. One of the great problems faced by Christian families at GMIT is domestic violence (Majelis Sinode, 2010; Zambrano et al., 2018). The awareness of the context of the KDRT that has been depicted in this ecclesiological manuscript should also be entrusted to the doctrine and program of the real church from the scope of the congregation, classicist, and Sinodal.

\subsection{Method}

The method used in this study is a qualitative descriptive method of research. Qualitative descriptive research performs careful measurements of certain social phenomena by developing concepts and collecting facts (Sutapa et al., 2017; Wiardani et al., 2018). According to Moleong "qualitative research is a study that intends to understand the

Dethan, M. A. P., Doeka, F. Y. A., Mansopu, L. H. F., \& Laki, R. R. (2019). Church efforts on strengthening women capacity to fight household violence in Kupang. International Research Journal of Management, IT and Social 
phenomenon of what is experienced by the subjects of research, e.g. behavior, perception, motivation, action and others, holistic instantly and by way of description in the form of Words and tongues, on a natural context and by utilizing natural methods (Maleong, 2012).

As for the subject of this study, women victims of KDRT at the Efata Liliba Church. According to Wirartha, the respondent sampling method is performed in purposive sampling, i.e. the sampling techniques are set intentionally based on certain criteria or considerations. Key figure respondents in the church, community leaders, activists who accompanied the victims of KDRT, a key figure of KDRT that considered sufficient understanding of the issue of KDRT (Wirartha, 2008).

The location of the selected area is GMIT Efata Liliba, Kupang City, located at Jalan Taebenu, Kupang, East Nusa Tenggara, Indonesia while the data collection techniques are conducted through interviews, observation of participation, and documentation studies (Junaidi, 2018; Kapoor, 2018).

\section{Results and Discussions}

Strengthening the capacity of GMIT women Efata Liliba is done with several ways, namely economic empowerment, the pastoral income of the church in the form of psychological counseling, advocacy law against victims as well as against the perpetrators. The victim was intended for the victims to be mentally and physically restored and able to pass through the trauma experienced. Against the perpetrator to change the mindset and stop the violence against wives and children, and or the last step leads the perpetrators to the court. In the case of Natalia Da Rosa where she was a victim of KDRT and her son and sexually abused sexual abuse and rape from her husband and father, for example, the church bravely strengthened the victim's mentally to report the case to the authorities, Although he was threatened by the perpetrators and the family of perpetrators, or invited to make peace but the perpetrator remained in his case. And after going through a lengthy and convoluted process, the perpetrators were convicted by the court and imprisoned in the detention house (Mulyani et al., 2017; Nasution, 2016).

The principles and strategies for strengthening the GMIT women's capacity are 1) They are empowering women through economic empowerment in a small scale household business. If the woman in the economy had her own money to fulfill her needs and her family, then her wife's dependence on her husband was diminished, and the woman would have self-esteem in her husband's eyes. Women's economic strength prevents KDRT;2) The church is a restoration institution for its citizens who are experiencing problems, both victims and perpetrators must be served and restored to the church as possible, through the pastoral ministry and counseling of the Church; 3) In conducting mentoring based on the non-judgmental principle that is not doing a negative assessment of women and children victims of KDRT, so the victims are not victims a second time; 4) The principle of egalitarian mentoring means equality between the companion and the victim. The companions did not present themselves as an all-out team of experts in the issue but with the victims found the source of the problem and how together they found their strength to overcome it; 5) The church must be a safe and trustworthy place for the victims to pour out the problem and get its way out. It means that the church is not only to allow them to be open to the problem but the church gives information on the rights of women in the eyes of God and the eyes of the law and gives advocacy of the law if necessary other than good psychological support In the period of experiencing the KDRT or recovery period thereafter; 6). The church also adheres to the principle of self-determination meaning decision making not on the church but to the victims themselves to determine its own life based on information, facts and considerations obtained; and 7). The church must maintain the confidentiality and identity of the outside parties so that the victims get a sense of security in people's lives now and later.

\section{Conclusion}

Strengthening the capacity of women to fight KDRT by GMIT Efata Liliba appears to be the result of the research showing its success. Success was seen not only economic empowerment in the form of livestock maintenance that makes GMIT women Efata Liliba has its own money and is stable in an economy but also GMIT Efata Liliba plays a role as an institutional Church that can be trusted to pour out problems of KDRT on one side, and on the other party GMIT Efata Liliba is able to build synergy with institutions and organization both NGOs and law enforcement, so as to accompany the victim maximum and ready to ensure their safe sense. From the results of the study shows that both the victims who have divorced and are still establishing their marital relationships, they live happily and look at 
tomorrow better. They live a healthy, psychologically and socially wholesome life in the community inside GMIT Efata Liliba. Psychologically healthy because their trauma has been healed and restored. It is theologically not to accept abusive treatment and harassment as fate and destiny from God. And socially social means to continue to work and be optimistic because it lives in the GMIT Efata Liliba, which gives a sense of security and protection.

Conflict of interest statement

The authors declared that they have no competing interest.

Statement of authorship

The authors have a responsibility for the conception and design of the study. The authors have approved the final article.

\section{Acknowledgments}

The authors would like to thank Artha Wacana Christian University for valuable time and support, and valuable advice so that this article can be solved and published.

Dethan, M. A. P., Doeka, F. Y. A., Mansopu, L. H. F., \& Laki, R. R. (2019). Church efforts on strengthening women capacity to fight household violence in Kupang. International Research Journal of Management, IT and Social Sciences, 6(5), 279-284. https://doi.org/10.21744/irjmis.v6n5.744 


\section{References}

Agra, I. B., Gelgel, I. P., \& Dharmika, I. B. (2018). Pressure on socio-cultural towards post-divorce Hindu women in Denpasar city. International Journal of Social Sciences and Humanities, 2(3), 63-78. https://doi.org/10.29332/ijssh.v2n3.191

Departemen Pendidikan Indonesia. (2008). Kamus Besar Bahasa Indonesia. Jakarta: Balai Pustaka.

Dewa, K. S. (2002). Pengantar Pelaksanaan Program Bimbingan dan Konseling. Jakarta: Rineka Cipta.

Hardiman, P., \& Simmonds, J. G. (2013). Spiritual well-being, burnout and trauma in counsellors and psychotherapists. Mental Health, Religion \& Culture, 16(10), 1044-1055. https://doi.org/10.1080/13674676.2012.732560

Jain, P., Agarwal, R., Billaiya, R., \& Devi, J. (2017). Women education in rural India. International Journal of Social Sciences and Humanities, 1(1), 21-26. https://doi.org/10.29332/ijssh.v1n1.12

Junaidi, L. M. (2018). Stereotypes as the Ideology of Feminism in Novels Authorized by Indonesian Female Authors. International Journal of Linguistics, Literature and Culture, 4(1), 1-15.

Kapoor, K. (2018). Representation of female characters through item songs in selected Hindi movies. International Journal of Social Sciences and Humanities, 2(1), 1-9. https://doi.org/10.29332/ijssh.v2n1.70

Majelis Sinode. (2010). Naskah Eklesiologi GMIT : Tata Gereja GMIT Tahun 2010. Kupang: Majelis Sinode GMIT.

Moleong, L. J. (2012). Metodologi penelitian kualitatif (Cet. Ke-30.). Bandung: Remaja Rosdakarya.

Mulyani, S., Subiyanto, A., Anantanyu, S., Respati, S. H., \& Wiboworini, B. (2017). Path analysis: knowledge, motivation factor, and their relationship with readiness to provide exclusive breastfeeding among pregnant women. International Research Journal of Management, IT and Social Sciences, 4(1), 8-14.

Nafi, T. H., Nurtjahyo, L. I., Kasuma, I., Parikesit, T., \& Putra, G. P. (2016). Peran hukum adat dalam penyelesaian kasus-kasus kekerasan terhadap perempuan di Kupang, Atambua, dan Waingapu. Jurnal Hukum \& Pembangunan, 46(2), 233-255. http://dx.doi.org/10.21143/jhp.vol46.no2.77

Nasution, S. N. (2016). Feminism study on marginalized women in the effort of empowerment. International Journal of Linguistics, Literature and Culture, 2(3), 144-150.

Natar, A. N. (2018). Gereja Yang Berpihak Pada Perempuan (Sebuah Eklesiologi Gereja Perspektif Feminis). Musãwa Jurnal Studi Gender dan Islam, 17(1), 51-61. https://doi.org/10.14421/musawa.1.171.51-61

Purwanto, F. (2018). Metode teologi gustaVe tHils. Jurnal Orientasi Baru, 20(2), 145-158.

Ruan, X. (2018). Engagement and negotiation: Exploring a tertiary female EFL teacher's professional agency in her career development in P.R. China. International Journal of Linguistics, Literature and Culture, 4(3), 46-63.

Rumah Perempuan Kupang. (2015). Catatan Akhir Tahun 2015. Kupang: Rumah Perempuan Kupang.

Suparna, I. K., Kumbara, A. N. A., \& Darmika, I. B. (2018). Homeopathy for breast cancer treatment towards Hindu women. International Journal of Health Sciences, 2(2), 25-36. https://doi.org/10.29332/ijhs.v2n2.118

Sutapa, I. K., Sutapa, I. N., \& Susila, I. N. D. (2017). Implementation of active rest in participatory ergonomics decrease workload and women musculoskeletal complaints of parking in mall Ramayana Denpasar. International Journal of Life Sciences, 1(2), 48-54. https://doi.org/10.21744/ijls.v1i2.42

Wiardani, N. K., Adiatmika, I., Paramita, D. P., \& Tirtayasa, K. (2018). Adult women perception towards obesity and its intervention strategies in the community. International Journal of Health Sciences, 2(2), 46-60. https://doi.org/10.29332/ijhs.v2n2.158

Wirartha, I. M. (2006). Pedoman Penulisan Usulan Penelitian, Skripsi dan Tesis. Yogyakarta: Andi Offset.

Wiryasaputra, Totok S. Ready to care: Pendampingan dan konseling psikologi. Galang Press, 2006.

Zambrano, M. L. V., Barreto, M. D. L. A. C., \& Chica, T. K. M. (2018). Intervention of social work in political participation of women in forming process of neighborhood councils of canton Portoviejo. International Journal of Social Sciences and Humanities, 2(1), 134-146. https://doi.org/10.29332/ijssh.v2n1.104 